\title{
THE SCIENTIFIC EXPERIENCE AS TEACHING REALITY
}

David Castro ${ }^{\mathrm{i}}$

Researcher, Primary Education, USA

\begin{abstract}
:
This article presents a study of the use of experiences from the natural and biological sciences in the classroom. The questioning of classical and traditional methods of teaching science, at the same time with the development of modern research in the psychology of learning and education, have led to revisions of the role of students and educators. The student is now seen as an active shaper of his own approach to knowledge and to the transformation of his daily experience into learning the physical and biological sciences. The teacher is treated as the critical intermediary between knowledge and the child and thus his role in the management of scientific experience is decisive but not transmissive. These issues are approached from different angles.
\end{abstract}

Keywords: scientific event, scientific experience, student representations of knowledge, teaching physical and biological sciences

\section{Introduction}

Criticism and weaknesses of traditional teaching practices to introduce the physical and natural knowledge and methods, namely the teaching interventions with the child as a dynamic participant and a cultural phenomenon in time, as a student's creative actionexperience, as perception and response has moved the research interest from the application of static teaching models to the study of students' mental representations about science concepts and physical phenomena as a more reliable way of understanding physical and biological science as well as the scientific experience itself (Bouzazi, 2019; Fragkiadaki \& Ravanis, 2015; Grigorovitch, 2015; Grigorovitch \& Nertivich, 2017; Jelinek, 2020). The questioning of the old tendency for science teaching in the classroom has also led to the questioning of the control teachers exercise over the teaching physical and biological concepts and phenomena, while it redefined the dynamics of the teacher's innovative role in which he is not a dominating factor but serves both as a mediator and as a facilitator (Castro, 2018; Delclaux \& Saltiel, 2013; Nertivich, 2016; Ntalakoura \&

i Correspondence: email castro.david2@gmail.com 
Ravanis, 2014; Syuhendri, 2017). In this context, a new point of view which has emerged and which regards the science experience as a main orientation for the development of an active citizen with all-round knowledge, enriched with knowledge from different disciplines, such as of the mental representations for the construction of biological and physical concepts and phenomena, or that of genetic, cognitive and educational psychology for the intellectual development of the individual, has the ability to transform the classroom into a place of continuous elevation of the subject construction and its parameters.

The encounter of the student with the physical world constitutes the science experience. Being a dynamic process as well as a communicative event this experience becomes both complex and important, the more so when it takes place in school as part of the teaching of physical and biological sciences. At least so it appears, judging by the intense theoretical debates and the various teaching experimentations it has given rise to so far. Despite the various suggestions put forward, however, we discern some reluctance, due to a theoretical inability or practical difficulties, to fully answer questions related to the nature of teaching science. These issues have been the subject of numerous conferences, editions, seminars, and debates among researchers and teachers around the world. But the teaching of biological and physical sciences especially in preschool and primary education is still under discussion, while the problems which crop up are occasionally addressed, but never fully solved, if, of course, we can assume that the complexity of the relevant problems could find a definitive solution (Arun, 2018; Boilevin \& Ravanis, 2007; Sotirova, 2017).

\section{The student's science experience}

In the case of different educational and teaching contexts, the reason that creates this condition appears to be various. We will approach the main one, which is also indicative of the contrastive nature of the views which determine teaching practice in preschool and primary education, namely the school programs and curricula. Very often the role of science is confused on the theoretical level and eventually conflicts on the practical level with the science teaching objectives, under which subject pure science is subsumed the being no teaching subject per se. In the main, the science experience of students ends with the declarative understanding of "laws" and cumulative "knowledge" or with their sensitization towards science, so that they may grow to enjoy and love them. What is not specified, however, is how within the existing rigid frameworks according to which every method is to be pressed to the service of the teaching of science (Hong \& Kang, 2010). On the other hand, what can be discerned is the confusion of terms and uncertainty of the method.

Although in a modern rationale there is not an explicit rejection of teaching, in the sense of "approaching" or "enjoyment", the danger exists of the student being even further removed from what is understood as the objective scientific literacy (Czerniak \& Johnson, 2014). Thus it becomes imperative that we reconsider the old attitude towards the exploitation of the children's naïve mental representations for teaching purposes, 
while there is the need to extend the semantic scope of children's thought in order to exploit its potentials to the full. Mainly it appears necessary to redefine the interpretativeteaching process as followed at present and to recognize the importance of the role of the main factor in the science teaching, i. e. the student, whose personal experience should not be distorted. The fact that until lately the recent scientific discoveries whether theoretical or empirical had not been exploited in this direction is to be attributed mainly to the domination of a book-oriented view of science which is identified with the childstudent who is involved in the science experience by realizing or taking knowledge of the science work through his own apprehension sensitivity and/or receptivity (Grigorovitch, 2016).

The theory, nevertheless, has always informed the teaching of science although it has never clearly disclosed its origins. Since the 1970s, due to the strengthening of constructivist ideas and approaches, the primacy of the book has declined. Many researchers reacting to the idea of an objectively content independent science work, have attributed to it the characteristics of an event in time, which has to be experienced (Kriwas, 1994; Mabejane \& Ravanis, 2018). They also question the validity of an absolutecorrect interpretation talking instead of many possible efficacy ones. Thus, is signaled a shift from the student's representations to the construction of the scientific models, a new attitude towards the nature of teaching science, and the practices it constituted. Teaching sciences is perceived not as an on-way process, but instead as a two-way one, involving three elements: the student, the teacher, and the matter subject and also their interactions which is able to activate the abilities both perceptual and cognitive of the child. These by functioning as structures embodying social as well as scientific codes, conventions, and examples taken from life, the science education research has shown that a scientific experience invites any kind of student to respond (Almeida, Lanca \& Goncalves, 2014; Fragkiadaki \& Ravanis, 2016; Kaliampos, 2015). Actually, in turn, activates his own everyday experience and contributes to the scientific-teaching event. The student attempts to structure meaning by making use of different cognitive resources, he combines them and expands them, thus developing and maturing both socially and cognitively.

Subsequently, the demand for a theory applicable to the teaching of physical and biological sciences should take into account, not only poles such as the curriculum and textbooks, but also the key factors in the constructivist approach, such as the student's involvement in teaching experience in a position of primary significance. The constructivist point of view in general encourages teachers and students to begin with an individual reaction, that is, always where they can start. This reaction makes greater use of the psychological experience, which it identifies with the personal one, while in claiming priority not for the typical and the general but for the idiosyncratic and singular, it expands it. It clearly emphasizes the student's experience as an individual, but it focuses on the everyday influence itself and its offshoots. As a stimulus, it activates elements of the student's past experiences of life in the social and natural environment, especially during the phase of evocation of the experience, that is, the student's first encounter with the signs. It invites the student to seek the meaning and establishes with 
him a dynamic interaction. It defines also some limits to the experience and essentially leads the student to check them and assess them according to his ideas and hypotheses. By wishing to fulfill his cognitive needs as successfully as he can, he marshals his mental references and invests them in his representations ultimately aiming at their transformation to a complete experience. Hence the physical knowledge does not exist as a series of printed texts, as a school subject matter or an ideal entity but operates like reality, as an everyday event which we experience not only while teaching, but also afterward. Thus, the physical knowledge becomes in its turn the process which itself initiates and the experience it constitutes for the student who moves to the second phase of the knowledge elaboration, the response itself. He judges himself in order to find out whether the emphasis he gives to the representational elements reflects the dynamics of the knowledge itself, and ultimately, by becoming aware of his reaction he makes his everyday living more comprehensible.

In this case, the student will need to transcend many times the limits of his own immediate experience and knowledge in order to take part in more complex and fuller experiences. In other words, it is possible for the student to resort to techniques like the ones described by the Piagetian Genetic Epistemology, namely assimilation and accommodation. Both assimilation, the transformation of external reality so that it can be embodied each time in the existing mental structures, and accommodation, as the modification of the existing structures so they can assimilate new elements from the environment, ensure the adaptation of the cognitive schemata, thus restoring the equilibration between the stimuli of the environment and the internal cognitive structures developed each time (Piaget, 1958). Thus, the basic premise of the Piagetian framework than a human interacts with the environment, and the related own that children are active rather than passive participants in their own development tallies with nature and the physical and biological sciences (Castro, 2013; Kokologiannaki \& Ravanis, 2013; Ozdemir, Guneysu \& Tekkaya, 2006). This view is reflected also by Vygotski (1962) when he points out that the major intellectual task facing children is their constant need to make sense of everything.

Whether the student perceives the physical knowledge as a stimulus or uses it in the classroom or in the laboratory he essentially recreates. He tries to appropriate its structured feel and to synthesize what he already knows and feels, with what the teaching situation, thus structuring knowledge in a spiral process. The student, who must constantly move between scientific knowledge and his representations, engages in a "give and take" relationship, that is, a transaction involving a mental negotiation that exploits interactions and cognitive conflicts (Parisi, 1988). The individual becomes a student through his relationship with the knowledge and by reacting to communicative or textual signs. The knowledge exists and comes to everyday life through its relation with the student. Each own becomes the other's environment. From the moment the student will manage to structure some kind of meaning, it is likely that he misinterprets the representational feel of things in the light of his experience. There exists nevertheless the possibility that the teaching procedure may be interrupted or frustrated because of a number of obstacles, such as the student's fixation or shift back to older experiences, 
unfamiliar signs, unusual ideas, representations or misconceptions when the student is forced to review or abandon his usual approaches and becomes confused. This idea tallies with the classic point of view in Science Education for a nonlinear process of the appropriation of the new physical knowledge (Pekdağ, 2010). Thus, a failed attempt at structuring meaning may block development, or give rise to a new one. In other words, the student has the option of selectively weighing his reaction to the various possibilities offered by the school classroom depending on the openness of the teaching situation and material itself. He can even determine the degree of realization of the process he experiences and the referential concepts, i. e. whether he will be content with the answers given by him personal representations or he will expand them by respectively adopting the new knowledge.

The various views that have been put forward so far do provide a theoretical framework capable of interpreting the science experience. However, there is no intention of constructing a compact model of teaching, some sort of prescription. There aren't researchers who attempt something like this, while most focus their efforts on the formulation of a framework of general principles of dominant ideas and organization of physical and biological sciences as an object of teaching and diffusion in the society (Kumar \& Nertivich, 2019; Lau, 2011). Ravanis (1994, 2005, 2017) for instance, although clearly stating his intention of reorganization the teaching methodology of science at the early childhood level, never gets to the point of actually offering a prescription for teaching purposes, but he proposes a spectrum of complementary theoretical concepts covering a holistic view of the development of children, of teacher's education and practices and of subject matter elements. Through his views, he attains a new synthesis of theorization of early childhood science education and its potential, while offering a framework to transfer his theoretical assumptions to the teaching practice. Besides the aim is not the teaching of physical and biological sciences as an independent subject at early childhood education. What is necessary is the assimilation of elements of the theoretical synthesis into the activities process, which is both feasible and can be done more effectively.

\section{The position and role of the teacher in the development of scientific experience}

The student should generally be encouraged to approach science in a personal way, to let himself "run", so that the science experience can make immediate sense to him. He should feel that his own reaction is worth expressing, even if it differs from his classmates' views or that of his teacher. Through a feeling of security derived from his relationship with the teacher and the class in general, the student will regain his spontaneity and will confidently be built each subsequent science experience. Those subsequent complete experiences will eventually make up the student's background and make possible the integration of each following relation with the science. Because for the proponents of the subjective version of the constructivist theory this is what the transactional nature of science teaching refers to the emergence and the negotiation of the science experience. 
But the question here is who exercises control. The constructivist framework attributes to the teacher the role of an intermediary (Brophy, 2006; Dumas Carré, WeilBarais, Ravanis \& Shourcheh, 2003; Linsin, 2013). Given his pedagogical relation with the student, it considers him as the most suitable to establish a procedure through which the student, by contributing from his own stock of science experiences, will become aware of his participation and will express his reaction in a number of ways. The teacher is aware of his students' individuality which could influence the appropriation of scientific knowledge, has to take care that the way they approach the physical and biological phenomena corresponds to their everyday life and is proportionate to the incentives the phenomena offers. He also needs to be aware of the whole range of representations, so that he can choose each time the ones which best meet the above-mentioned specifications. Certainly, such a thing cannot happen within the rigid framework of the school curriculum and textbooks but only on the basis of a freer relation with the science in society. If we take into account the fact that the student is usually called upon to write or to think beyond the experience he has had with the science phenomena we understand how catalytic the role of the teacher can be in ensuring that this relationship is indeed a productive one. Obviously, this by no means excludes overt teaching through the use of traditional activities which have mostly to do with the elaboration of the scientific content like the laboratory exercise or the reading of textbooks. There is no question that these have to be taught at some stage in order to facilitate the completion of the scientific experience. However, this should not be turned into an end in itself or to be taught each time, but only when this is deemed necessary. After all, every scientific acquisition, whether at school or elsewhere, has to begin and end in a comprehensible way.

It is important dot the teacher to have critically realized and evaluated his own reactions to the work he offers his class, and to have understood that both his own views and these of others will be of value to the student only if he understands them as similar and not contradictory to his own, or at least familiar and accessible to him. Thus, the teacher will be able to shed his prejudices, or at least to avoid to project them, thus turning the relation between the student and the scientific work into an exchange of experience with other students or himself. Then he will be able both to help the students in their attempt to organize their reactions and to extend them through the reaction of others (Hoang, 2019; Kada \& Ravanis, 2016; Kocakülah, 2006).

The relation of the student with the scientific event is immediate, just as is that of the relation of the teacher with the event. Teachers and students transact with the scientific knowledge, in a two-way process established between them (Marzano, Marzano \& Pickering, 2003). The fact that student transacts with the knowledge on the same level indicates the equality or equivalence of the relation. The fact however that the teacher is specially trained does not mean that he is in charge of the whole scientific teaching event, but that he operates from a different basis than the one on which the other two participants in the science relation are, namely the knowledge and the student. The relationship between the teacher and the student is characterized by reciprocity but without anyone having a dominant position in communication. The teacher by sticking to his supervisory role as an intermediary has as his main objective to maintain the 
science experience in the center of each attempt to access it, and to protect the individuality of each student by considering him to be the main person in the scientific event.

\section{Discussion}

To summarize the above, we can say that the theory and research in Science Education and its teaching implications cannot and should not become an introverted and selfreferential field of scientific knowledge. As an attitude towards physical and biological sciences and the scientific experience, this has already been checked and we need to avoid falling into the same trap. The new view that seems to be emerging signals a different general way of viewing both the representational nature of the scientific thinking and the teaching condition, a different conceptualization operating on many levels. It restrains the insistence of traditional teaching practice to persuade the student about the validity of the one and only science interpretation, it recognizes the possibility of multiple valid interpretations, and it draws on the findings of theory in order to bring the science experience of the school classroom or laboratory closer to the real conditions in which science is produced and consumed.

It presents the scientific event as a dynamic process and a creative actionexperience on the part of the student, while it attributes to it the qualities of a cultural phenomenon and the validity of psychological knowledge. It avoids also the application of static instructional models advocating instead freer forms of teaching, during which the participants of the scientific event are released from constraints and are able to be active and productive. As a final point, by focusing its interest on the study of student's representations and reactions, since it links the scientific knowledge not just with its a mechanical reception but mainly with the reaction it provokes, as the most reliable way of realizing the nature of scientific explanation and its experience, it is able to ensure reliability in every critical process and to expand every kind of teaching practice.

\section{References}

Almeida, A., Lanca, C., \& Goncalves, C. (2014). Concecoes e representacoes de criancas e de professores em formacao acerca dos animais: Das similaridades aos desafios colocados. In G. Portugal, A. I. Andrade, C. Tomaz, F. Martins, J. A. Costa, M. R. Migueis, R. Neves \& R. M. Vieira. (Orgs.). Formacao inicial de professores e educadores: experiencias em contexto portugues (pp. 61-71). Aveiro: UA Editora.

Arun, Z. (2018). Questions sur la formation initiale des enseignants en didactique des sciences: une vision alternative. European Journal of Alternative Education Studies, 3(1), 44-53.

Boilevin, J.-M., \& Ravanis, K. (2007). L'éducation scientifique et technologique à l'école obligatoire face à la désaffection: recherches en didactique, dispositifs et références. Skholê, $H S(1), 5-11$. 
Brophy, J. (2006). History of research on classroom management. In C. M. Evertson \& C. S. Weinstein (Eds.), Handbook of classroom management: Research, practice, and contemporary issues (pp. 17-43). Mahwah, NJ: Lawrence Erlbaum Associates.

Bouzazi, R. (2019). Conceptions de la respiration chez des élèves tunisiens du cycle préparatoire et du cycle secondaire de l'enseignement. Educational Journal of the University of Patras UNESCO Chair, 6(2), 114-126.

Castro, D. (2013). Light mental representations of 11-12 year old students. Journal of Social Science Research, 2(1), 35-39.

Castro, D. (2018). L'apprentissage de la propagation rectiligne de la lumière par les élèves de 10-11 ans. La comparaison de deux modèles d'enseignement. European Journal of Education Studies, 4(5), 1-10.

Czerniak, C. M., \& Johnson, C. C. (2014). Interdisciplinary science teaching. In: S. K. Abell, \& N. G. Lederman (Eds.), Handbook of research on science education (2nd Ed.) (pp. 395-411). London and New York: Routledge.

Delclaux, M., \& Saltiel, E. (2013). Caractéristiques d'un enseignement des sciences fondé sur l'investigation et évaluation de dispositifs d'accompagnement des enseignants. Review of Science, Mathematics \& ICT Education, 7(2), 35-51.

Dumas Carré, A. Weil-Barais, A. Ravanis, K., \& Shourcheh, F. (2003). Interactions maîtreélèves en cours d'activités scientifiques à l'école maternelle: approche comparative. Bulletin de Psychologie, 56(4), 493-508.

Fragkiadaki, G., \& Ravanis, K. (2015). Preschool children's mental representations of clouds. Journal of Baltic Science Education, 14(2), 267-274.

Fragkiadaki, G., \& Ravanis, K. (2016). Genetic research methodology meets Early Childhood Science Education Research: a Cultural-Historical study of child's scientific thinking development. Cultural-Historical Psychology, 12(3), 310-330.

Grigorovitch, A. (2015). La formation des ombres : représentations mentales des élevés de 7-9 ans. Educational Journal of the University of Patras UNESCO Chair, 2(2), 102109.

Grigorovitch, A. (2016). L'approche des manuels scolaires: comprendre, créer, utiliser, discuter, évaluer. Educational Journal of the University of Patras UNESCO Chair, 3(1), 67-73.

Grigorovitch, A., \& Nertivich, D. (2017). Représentations mentales des élevés de 10-12 ans sur la formation des ombres. European Journal of Education Studies, 3(5), 150160.

Hoang, V. (2019). L'enseignement de la physique à partir des représentations : un projet collaboratif. European Journal of Education Studies, 6(9), 306-315.

Hong, M., \& Kang, N.-H. (2010). South Korean and the us secondary school science teacher's conceptions of creativity and teaching for creativity. International Journal of Science and Mathematics Education, 8(5), 821-843.

Jelinek, J. A. (2020). Children's Astronomy. Shape of the earth, location of people on earth and the day/night cycle according to polish children between 5 and 8 years of age. Review of Science, Mathematics \& ICT Education, 14(1), 69-87. 
Kada, V. \& Ravanis, K. (2016). Creating a simple electric circuit with children between the ages of five and six. South African Journal of Education, 36(2), 1-9.

Kaliampos, G. (2015). A small scale, qualitative study on exploring alternative conceptions of mechanics in students with autism. Educational Journal of the University of Patras UNESCO Chair, 2(2), 112-122.

Kocakülah, A. (2006). The effect of traditional teaching on primary, secondary and university students' conceptual understanding of image formation and colours. Balikesir: Balikesir University.

Kokologiannaki, V., \& Ravanis, K. (2013). Greek sixth graders mental representations of the mechanism of vision. New Educational Review, 33(3), 167-184.

Kriwas, S. (1994) Emotional, ethical and cognitive aspects of the environmental education of children and adolescents. Paper presented in the Conference about Environmental Education of the Department of Education/University of Thessaloniki.

Kumar, S., \& Nertivich, D. (2019). Science in society awareness among Indian and Russian students: emotional aspects. European Journal of Social Sciences Studies, 4(2), 1-14.

Lau, J. Y. F. (2011). An introduction to critical thinking and creativity: think more, think better. New Jersey: John Willey \& Sons Inc.

Linsin, M. (2013). The classroom management secret: And 45 other keys to a well-behaved class. San Diego, CA: JME Publishing.

Mabejane, M. R., \& Ravanis, K. (2018). Linking teacher coursework training, pedagogies, methodologies and practice in schools for the undergraduate science education student teachers at the National University of Lesotho. European Journal of Alternative Education Studies, 3(2), 67-87.

Marzano, R., Marzano, J. S., \& Pickering, D. J. (2003). Classroom management that works: Research-based strategies for every teacher. Alexandria, VA: Association for Supervision and Curriculum Development.

Nertivich, D. (2016). Représentations des élevés de 11-12 ans pour la formation des ombres et changement conceptuel. International Journal of Progressive Sciences and Technologies, 3(2), 103-107.

Ntalakoura, V., \& Ravanis, K. (2014). Changing preschool children's representations of light: a scratch based teaching approach. Journal of Baltic Science Education, 13(2), 191-200.

Ozdemir, P., Guneysu, S., \& Tekkaya C. (2006). Enhancing learning through multiple intelligences. Journal of Biological Education, 40(3), 74-78.

Parisi, M. (1988). Niveaux d'organisation cognitive et perméabilité au conflit sociocognitif. In A. N. Perret-Clermont \& M. Nicolet (Eds.), Interagir et connaître (pp. 29-40). Fribourg: Delval.

Pekdağ, B. (2010). Alternative methods in learning chemistry: learning with animation, simulation, video and multimedia. Journal of Turkish Science Education, 7(2), 79-110.

Piaget, J. (1958). Assimilation et connaissance. In J. Piaget (Ed.), La lecture de l'expérience (pp. 49-107). Paris: PUF. 
Ravanis, K. (1994). The discovery of elementary magnetic properties in pre-school age. A qualitative and quantitative research within a piagetian framework. European Early Childhood Education Research Journal, 2(2), 79-91.

Ravanis, K. (2005). Les Sciences Physiques à l'école maternelle: éléments théoriques d'un cadre sociocognitif pour la construction des connaissances et/ou le développement des activités didactiques. International Review of Education, 51(2/3), 201-218.

Ravanis, K. (2017). Early Childhood Science Education: state of the art and perspectives. Journal of Baltic Science Education, 16(3), 284-288.

Sotirova, E.-M. (2017). L'apprentissage en sciences expérimentales : la recherche et l'enseignement. European Journal of Education Studies, 3(12), 188-198.

Syuhendri, S. (2017). A learning process based on conceptual change approach to foster conceptual change in Newtonian mechanics. Journal of Baltic Science Education, 16(2), 228-240.

Vygotsky, L.-S. (1962). Thought and Language. Cambridge Ma.: MIT Press. 
David Castro

THE SCIENTIFIC EXPERIENCE AS TEACHING REALITY

Creative Commons licensing terms

Authors will retain the copyright of their published articles agreeing that a Creative Commons Attribution 4.0 International License (CC BY 4.0) terms will be applied to their work. Under the terms of this license, no permission is required from the author(s) or publisher for members of the community to copy, distribute, transmit or adapt the article content, providing a proper, prominent and unambiguous attribution to the authors in a manner that makes clear that the materials are being reused under permission of a Creative Commons License. Views, opinions and conclusions expressed in this research article are views, opinions and conclusions of the author(s). Open Access Publishing Group and European Journal of Alternative Education Studies shall not be responsible or answerable for any loss, damage or liability caused in relation to/arising out of conflict of interests, copyright violations and inappropriate or inaccurate use of any kind content related or integrated on the research work. All the published works are meeting the Open Access Publishing requirements and can be freely accessed, shared, modified, distributed and used in educational, commercial and non-commercial purposes under a Creative Commons Attribution 4.0 International License (CC BY 4.0). 